\title{
Hodgkin's disease: immunoglobulin heavy and light chain gene rearrangements revealed in single Hodgkin/Reed-Sternberg cells
}

\author{
F Deng, G Lü, G Li, G Yang
}

\begin{abstract}
Aim-To corroborate and investigate the nature of Hodgkin/Reed-Sternberg cells (H/R-S) of various subtypes of Hodgkin's disease.
\end{abstract}

Method-Single H/R-S cells were micropicked from frozen sections of tissues affected by Hodgkin's disease. The DNA from these cells was amplified by the polymerase chain reaction (PCR) with immunoglobulin heavy chain (IgH) gene FRIIIa/JH primers and light chain gene family specific primers.

Results-Fifty two of 135 isolated cells gave specific reaction products $(36 \%)$. IgH and $V_{k 4}$ gene rearrangements were found repeatedly in many $H / R-S$ cells from one case of lymphocyte predominant Hodgkin's disease. Repeated $V_{k 4}$ and individual $\mathrm{IgH} / \mathrm{V}_{\mathrm{k} 4,2}$ rearrangements were seen in one case, and individual IgH and $\mathrm{V}_{\lambda 3} / \mathrm{V}_{\mathrm{k} 4}$ rearrangements were seen in another case of nodular sclerosis-type Hodgkin's disease. Repeated IgH/ $\mathbf{V}_{\lambda 3}$ and individual $V_{\lambda 2,4}$ rearrangements, repeated $V_{k 4}$ and individual IgH/ $V_{k 3}$ rearrangements, and repeated IgH and individual $\mathrm{V}_{\mathrm{k} 3} / \mathrm{V}_{\mathrm{k} 4}$ rearrangement were detected, respectively, in three cases of mixed cellularity-type Hodgkin's disease. Repeated and individual IgH rearrangements were found in another two cases of mixed cellularity-type Hodgkin's disease. Conclusion-The H/R-S cells isolated from lymphocyte predominant Hodgkin's disease had IgH and $V_{k 4}$ gene rearrangements, which supports the conclusion that this disease results from a proliferation of neoplastic B ce1ls. The IgH and $\kappa$ and/or $\lambda$ gene rearrangements seen in H/R-S cells isolated from classic Hodgkin's disease (mixed cellularity-type and nodular sclerosis-type) support the theory that these cells derive from $B$ lineage cells at various stages of differentiation. To our knowledge, this is first time that $\lambda$ gene rearrangements have been detected in H/R-S cells.

(F Clin Pathol: Mol Pathol 1999;52:37-41)

Keywords: Hodgkin's disease; Hodgkin and ReedSternberg cells; immunoglobulin gene rearrangements

Pathology, West China

University of Medical

Science

$\mathrm{G} \mathrm{Li}$

G Yang

Correspondence to:

Dr Deng.

Accepted for publication 21 July 1998 ever, the detection of $\mathrm{B}$ and $\mathrm{T}$ cell associated antigens does not necessarily imply that these proteins, which might be absorbed from the microenvironment, are synthesised by the $\mathrm{H} / \mathrm{R}-\mathrm{S}$ cells. In situ hybridisation detected $\kappa$ light chain mRNA in lymphocytic and/or histiocytic cells of lymphocyte predominant Hodgkin's disease $\mathrm{e}^{2-4}$; however, a similar positive signal has not been detected in H/R-S cells of classic Hodgkin's disease ( $\mathrm{R}$ Von Wasielewski, et al. Presented at the third international symposium on Hodgkin's lymphoma, Cologne Germany, 1995). Southern blot hybridisation and routine polymerase chain reaction (PCR) for immunoglobulin or $\mathrm{T}$ cell receptor gene rearrangement does not allow an accurate explanation of the origin of clonal or polyclonal gene rearrangements, ${ }^{1}$ and it is most likely that these gene rearrangements result from the large background population of cells in the tissue of Hodgkin's disease. Therefore, it is very difficult to determine the cell lineage of H/R-S cells because Hodgkin's disease has special histological characteristics distinct from other tumours: a small number of H/R-S cells (usually less than $1 \%$ ) among a large number of reactive background cells. A major obstacle in defining the nature of $\mathrm{H} / \mathrm{R}-\mathrm{S}$ cells has been obtaining a pure population for study. Molecular analysis of single H/R-S cells is the best way to confirm the nature of these cells.

In 1994, Küppers et al picked single H/R-S cells from histological sections of Hodgkin's disease tissue and found that these cells had immunoglobulin heavy chain $(\operatorname{IgH})$ and $\kappa$ light chain gene rearrangements. ${ }^{5}$ In fact, the method (molecular histology) is an improved technique for the extraction of cell DNA, which excludes the DNA of background cells from the template DNA and allows one to determine unambiguously the origin of amplification products. In their report, the DNA from single H/R-S cells was amplified with IgH and $\kappa$ light chain gene family specific primers, ${ }^{6}$ but not with a $\lambda$ light chain gene primer (the reason that light chain restriction almost always involves the $\kappa$ light chain remains to be explained). No $\kappa$ light chain gene rearrangements were found in the single H/R-S cells obtained from nodular sclerosis-type Hodgkin's disease tissue samples. However, the possibility that these H/R-S cells derived from another cell lineage ( $\mathrm{T}$ cells) cannot be excluded entirely because $T$ cell associated antigens are found on H/R-S cells in this subtype of Hodgkin's disease. ${ }^{15}$ 

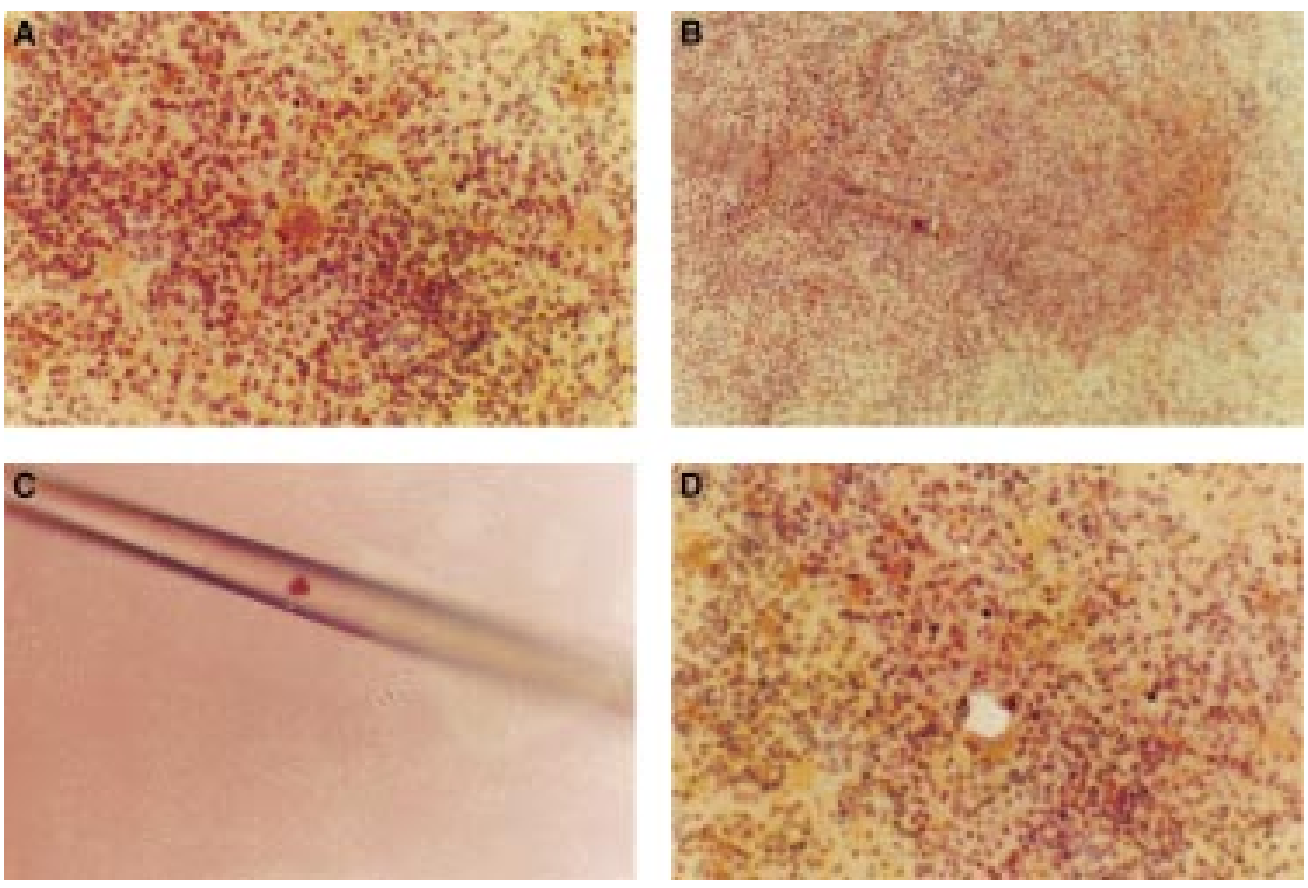

Figure 1 Procedure for isolating a single H/R-S cell. (A) A typical H/R-S cell is shown in the middle of the picture, with a double nucleus and CD30 positive cytoplasm. Haematoxylin and eosin stained; magnification, $\times 200$. (B) Picking the cell up with the micropipette. (C) The H/R-S cell in the micropipette. (D) After isolation of the cell, there is a hole where the cell was located, with a small rim of cytoplasm and nucleus.

In our study, we micropicked single $\mathrm{H} / \mathrm{R}-\mathrm{S}$ cells from frozen tissue sections. PCR for Ig gene rearrangements was performed with an $\operatorname{IgH}$ chain gene common primer and $\kappa$ and $\lambda$ light chain gene family specific primers, with the aim of further investigating the nature of H/R-S cells.

\section{Methods}

TISSUES

Frozen lymph nodes affected by Hodgkin's disease (one case of lymphocyte predominant Hodgkin's disease, two cases of nodular sclerosis-type Hodgkin's disease, and five cases of mixed cellularity-type Hodgkin's disease) came from the Department of Pathology, West China University of Medical Science.

\section{IMMUNOHISTOCHEMISTRY}

Frozen sections (10-15 $\mu \mathrm{m}$ thick) were cut and immunostained with $\mathrm{BerH}_{2}$, (Dakopatts, Glostrup, Denmark). The slides were counterstained with haematoxylin. In addition, the sections of paraffin wax embedded tissue were immunostained with anti- $\kappa$ and anti- $\lambda$ light chain monoclonal antibodies (Dackopatts).

ISOLATION OF SINGLE H/R-S CELLS

The stained, frozen sections were incubated with $5 \mathrm{mg} / \mathrm{ml}$ collagenase (Boehringer, Mannheimn, Germany) for three to four hours at $56^{\circ} \mathrm{C}$. Under the microscope at a certain magnification, the single H/R-S cells with CD30 positive stained cytoplasm were carefully isolated using a micropipette $(20-25 \mu \mathrm{m}$ in diameter) attached to a hydraulic micromanipulator (WR-89; Nairishiger, Japan), and then transferred to Eppendorf tubes that contained $32 \mu \mathrm{l}$ $1 \times$ PCR buffer and stored at $-20^{\circ} \mathrm{C}$ (fig 1 ).
PCR OF SINGLE H/R-S CELLS

The primers used for analysis of $\operatorname{IgH}$ chain gene rearrangement contained FRIIIa that was designed for the third framework region of the $\mathrm{V}_{\mathrm{H}}$ region, and $\mathrm{LJH}$ and $\mathrm{VLJH}$ that were designed for the $\mathrm{J}_{\mathrm{H}}$ region. The amplification of the $\mathrm{V}_{\mathrm{H}} \mathrm{D}_{\mathrm{H}} \mathrm{J}_{\mathrm{H}}$ fragment yields a product of $\sim 80$ $120 \mathrm{bp}$ in length. ${ }^{7-9}$ Family specific primers were used for detecting both light chain gene rearrangements. ${ }^{10}{ }^{11} \mathrm{It}$ is possible to differentiate monoclonal from polyclonal B cell proliferation. In a clonal population, only one or two $\mathrm{V}$ genes are rearranged and give rise to a PCR product in the reaction with the $\mathrm{V}$ primer of the respective $\mathrm{V}$ gene family, whereas in a polyclonal population all, or at least most, of the $\mathrm{V}$ gene family rearrangements are present. Both the light chain gene family specific primers were designed for the framework region I. The amplified fragment is $\sim 350 \mathrm{bp}$ in length. ${ }^{10}{ }^{11}$

A semi-nested PCR approach was chosen ${ }^{6}$ and carried out using a PE480 DNA hot cycle appliance. Single cells in Eppendorf tubes were incubated with $0.25 \mathrm{mg} / \mathrm{ml}$ proteinase $\mathrm{K}$ for two hours at $56^{\circ} \mathrm{C}$. The enzyme was inactivated bv heating to $95^{\circ} \mathrm{C}$ for 10 minutes. The first round of amplification was carried out in $50 \mu \mathrm{l}$ volumes that contained $50 \mathrm{mM} \mathrm{KCl}, 10$ $\mathrm{mM}$ Tris- $\mathrm{HCl}$ ( $\mathrm{pH} 8.4$ ), 0. 01\% gelatin, $2.5 \mathrm{mM} \mathrm{MgC1} 1_{2}, 800 \mu \mathrm{M}$ dNTPs, $2.8 \mathrm{nM}$ each of the FRIIIa and LJH primers, or a mixture of all $\mathrm{V}_{\kappa}$ and $\mathrm{J}_{\kappa}$ primers, or a mixture of all $\mathrm{V}_{\lambda}$ and $\mathrm{J}_{\lambda}$ primers, and $2 \mathrm{U}$ Taq DNA polymerase, hot start. The cycle programme consisted of 40 cycles of $95^{\circ} \mathrm{C}$ for 90 seconds, $59^{\circ} \mathrm{C}$ for $30 \mathrm{sec}-$ onds, and $72^{\circ} \mathrm{C}$ for 80 seconds. In the first round, we added $2.8 \mathrm{nM}$ each of three $\beta$-globin primers (PC40, GH2O, and PE) to determine whether it would be appropriate to perform the 
second round of amplification. A specific product of $268 \mathrm{bp}$, detected by polyacrylamide gel electrophoresis, implied that the DNA from a single H/R-S cell was suitable for the second round of amplification.

The second round of amplification was carried out in separate reactions for VLJH and each of the $\mathrm{V}_{\mathrm{K}}$ or $\mathrm{V}_{\lambda}$ family specific primers, using $2 \mu \mathrm{l}$ of the first round reaction mixture in a $50 \mu \mathrm{l}$ volume that contained $50 \mathrm{mM} \mathrm{KC1}$, $10 \mathrm{mM}$ Tris-HC1 (pH 8.4), $0.01 \%$ gelatin, $2.5 \mathrm{mM} \mathrm{MgCl}, 800 \mu \mathrm{M}$ dNTPs, $0.2 \mu \mathrm{M}$ of each FRIIIa and VLJH, or $0.25 \mu \mathrm{M}$ of each $\mathrm{V}_{k}$ and $\mathrm{J}_{\kappa}$ primer mixture, or each $\mathrm{V}_{\lambda}$ and $\mathrm{J}_{\lambda}$ primer mixture, and $2 \mathrm{U}$ of Taq DNA polymerase, hot start. The cycle programme consisted of 40 cycles of $95^{\circ} \mathrm{C}$ for 90 seconds, $61^{\circ} \mathrm{C}$, for 30 seconds, and $72^{\circ} \mathrm{C}$ for 80 seconds. A $10 \mu \mathrm{l}$ aliquot of the reaction mixture was analysed on an $8 \%$ polyacrylamide gel. The amplified products were visualised under ultraviolet light after ethidium bromide staining.

\section{CONTROL EXPERIMENTS}

One case of a follicular centre cell lymphoma was used as a positive control for the detection of $\operatorname{IgH}$ chain gene rearrangement. One case of lymphadenopathy was used as a positive control for amplification with both light chain gene primers. In negative controls no DNA was added.

\section{Results}

CONTROL EXPERIMENTS

In the positive control, a specific $80 \mathrm{bp}$ band was seen after electrophoresis. The amplification with DNA from the tissue sample of lymphadenopathy gave rise to a product of $\sim 350 \mathrm{bp}$ in reactions with every $\kappa$ and $\lambda$ gene family specific primer, which indicated that a polyclonal population of B cells was present in the specimen. Therefore, we concluded that the PCR method and family specific primers that we were using were suitable for detecting Ig gene rearrangements in single H/R-S cells. No bands were seen in the negative control.

\section{IMMUNOHISTOCHEMISTRY}

Both light chain proteins and the CD30 antigen were demonstrated in H/R-S cells from each case of classic Hodgkin's disease (mixed cellularity-type and nodular sclerosis-type). Only the $\kappa$ light chain was found in H/R-S cells of lymphocyte predominant Hodgkin's disease (fig 2).

PCR ANALYSIS OF SINGLE H/R-S CELLS

PCR specific products of the $\operatorname{IgH}, \kappa$, and $\lambda$ genes were not amplified from all single cells. There are several possible reasons for this (which might prove to be methological limitations) $)^{5}{ }^{12}{ }^{13}$ : (1) part of the cell nucleus may have been missing: the larger the cell, the lower the likelihood of obtaining the entire cell nucleus; (2) certain unknown $\mathrm{V}$ gene rearrangements might not be detected with the primers used; (3) DNA might be destroyed in the histological tissue processing; (4) some genes might have the germline configuration; and (5) the chosen primers might not cover all

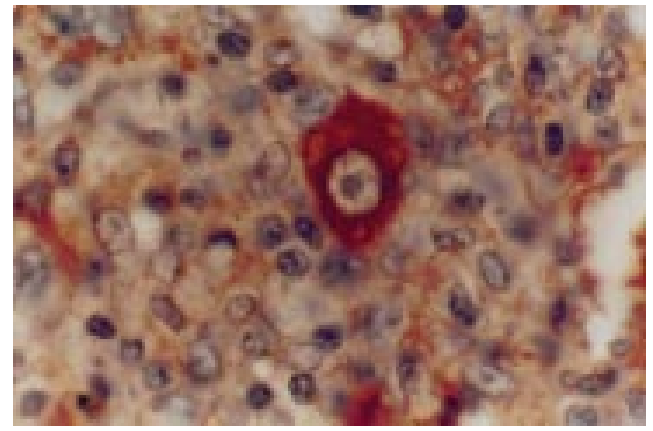

Figure 2 Patient 1 (lymphocyte predominant Hodgkin's disease). A typical Hodgkin cell is seen in the middle of the section, with the cytoplasm immunostained positively for the $\kappa$ light chain. Avidin-biotin complex stained; magnification $\times 1000$.

regions of the $\mathrm{V}$ gene. For example, FRIIIa is designed for the third framework region of $\mathrm{V}_{\mathrm{H}}$, it hybridises to the $3^{\prime}$ end of most $\mathrm{V}_{\mathrm{H}}$ genes. However, with this primer, no information can be obtained about the particular $\mathrm{V}_{\mathrm{H}}$ genes rearranged, such as FRI/JH, FRII/JH rearrangements and even bcl-2/JH translation. The sensitivity in our study was $\sim 35.8 \%$.

Unlike the method proposed by Küppers et $a l$, in our method we added $\beta$-globin gene primers to the first round of amplification to determine the usefulness of performing the next round of amplification. We showed that it was not necessary to carry out the next round of amplification if the $\beta$-globin gene specific product was not detected in the first round (its presence indicates that DNA is available from the single cell), thereby reducing the number of PCR reactions that were carried out, and economising on reagents and time.

Fifty two of 135 single H/R-S cells isolated showed specific products in PCR reactions $(36 \%)$. In the IgH gene, all the amplification products of single cells from a given biospy specimen were the same length $(80 \mathrm{bp})$. In the $\operatorname{Ig} \kappa$ and $\lambda$ light chain genes, the lengths of the products were also the same $(350 \mathrm{bp})$.

In our study, many individual H/R-S cells were isolated from frozen sections. In most cases, many H/R-S cells from the same specimen produced a PCR product of the same size ( $80 \mathrm{bp}$ for $\operatorname{IgH}, 350 \mathrm{bp}$ for the light chain gene family). Therefore, there is a strong likelihood that these H/R-S cells are a clonal expansion or a monoclonal B cell population.

In addition, $\mathrm{IgH}$ and $\mathrm{V}_{\mathrm{k} 4}$ family products were found repeatedly in many H/R-S cells from one case of lymphocyte predominant Hodgkin's disease. In two cases of nodular sclerosis-type Hodgkin's disease, repeated $\mathrm{V}_{\mathrm{K} 4}$ and individual $\operatorname{IgH} / \mathrm{V}_{\mathrm{k} 2,4}$, and individual $\operatorname{IgH}$ and $\mathrm{V}_{\lambda_{3}} / \mathrm{V}_{\mathrm{k} 4}$ products were seen (fig 3). In five cases of mixed cellularity-type Hodgkin's disease, repeated $\operatorname{IgH} / \mathrm{V}_{\lambda 3}$ and individual $\mathrm{V}_{\lambda 2,4}$, repeated $\mathrm{V}_{\mathrm{k} 4}$ and individual $\mathrm{IgH} / \mathrm{V}_{\mathrm{k} 3}$, and repeated $\operatorname{IgH}$ and individual $\mathrm{V}_{\mathrm{k} 3} / \mathrm{V}_{\mathrm{k} 4}$ family products were detected, respectively (fig 4).

In patient 3 (nodular sclerosis-type Hodgkin's disease) and patient 7 (mixed cellularitytype Hodgkin's disease), one H/R-S cell had two light chain gene family rearrangements $\left(\mathrm{V}_{\mathrm{\kappa} 2}\right.$ and $\mathrm{V}_{\mathrm{k} 4}$ family in patient $3, \mathrm{~V}_{\lambda 2}$ and $\mathrm{V}_{\lambda 4}$ 


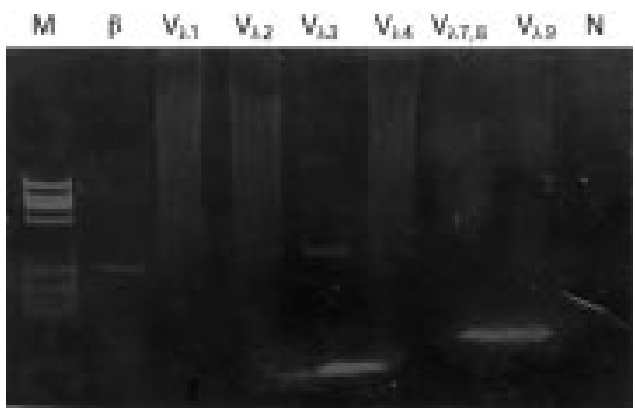

Figure 3 Polyacrylamide gel electrophoresis of the amplification products of a single H/R-S cell from patient 2 (nodular sclerosis-type Hodgkin's disease), in the reaction with every $V$ gene family primer of the $\lambda$ light chain. $M$, PBR322/HaeIII molecular weight marker; $\beta$, $\beta$-globin gene PCR product; $N$, negative control. The products from this cell showed a specific band of about $350 \mathrm{bp}$ in length in the reaction with the $V_{13}$ family primer.

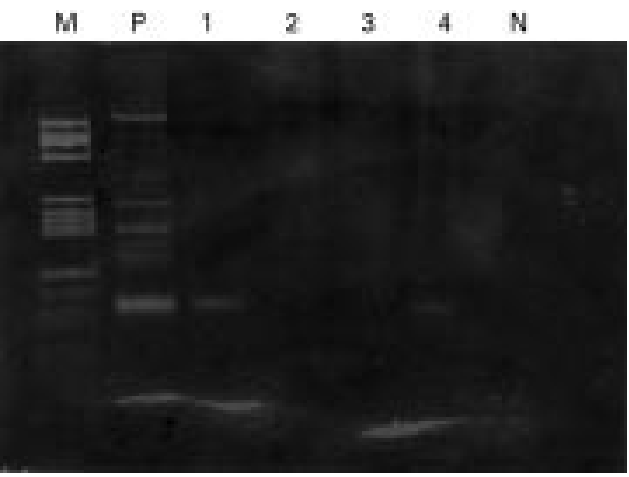

Figure 4 Polyacrylamide gel electrophoresis of the amplification products of a single $H / R-S$ cell from patient 6 (mixed cellularity-type Hodgkin's disease), in the reaction with the $V_{H}$ gene primer. M, PBR322/HaeIII molecular weight marker; $P$, positive control, a case of follicular centre cell lymphoma; $N$, negative control; lanes 1 to 4 are four single $H / R-S$ cells. Specific bands of 80 bp were seen in lanes 1 and 4 .

family in patients 7). This rearrangement might be just on two chromosomes (bi-allelic) and presumably on more than two chromosomes in a hyperploid H/R-S cell.

Table 1 summarises the results of immunoglobulin gene rearrangements in single H/R-S cells of eight patients with Hodgkin's disease.

\section{Discussion}

The neoplastic elements of Hodgkin's disease-H/R-S cells and their variants-have been identified variously as $\mathrm{B}$ or $\mathrm{T}$ lym-

Table 1 Summary of single H/R-S cells analysis of eight cases of Hodgkin's disease for Ig gene rearrangements

\begin{tabular}{|c|c|c|c|c|c|c|c|c|c|}
\hline \multirow[b]{2}{*}{ Patient } & \multirow{2}{*}{$\begin{array}{l}\text { Picked } \\
\text { cells }\end{array}$} & \multirow{2}{*}{$\begin{array}{l}\beta \text {-globin } \\
\text { positive cells }\end{array}$} & \multicolumn{7}{|c|}{ No of cells with rearrangements of Ig gene } \\
\hline & & & $\operatorname{IgH}$ & $V_{k 3}$ & $V_{\kappa 4}$ & $V_{\kappa 2,4}$ & $V_{\lambda 2,4}$ & $V_{73}$ & $V_{\lambda 4}$ \\
\hline 1 (LPHD) & 14 & 8 & 2 & & 2 & & & & \\
\hline 2 (NSHD) & 14 & 7 & 1 & & 1 & & & 1 & \\
\hline 3 (NSHD) & 14 & 8 & 1 & & 2 & 1 & & & \\
\hline $4(\mathrm{MCHD})$ & 28 & 21 & 6 & 1 & & & & & 1 \\
\hline 5 (MCHD) & 14 & 7 & 1 & & 2 & & & 1 & \\
\hline 6 (MCHD) & 9 & 5 & 2 & & & & & & \\
\hline 7 (MCHD) & 48 & 42 & 14 & 2 & & & 1 & & \\
\hline 8 (MCHD) & 4 & 4 & 1 & & & & & & \\
\hline
\end{tabular}

Illustration: for example, in patient 4, a total of $28 \mathrm{H} / \mathrm{R}-\mathrm{S}$ cells were isolated. In the first round of amplification, $\beta$-globin gene specific product was detected in 21 cells, of which six cells revealed IgH rearrangement, one cell revealed $V_{k 3}$ family rearrangement, and one cell revealed $V_{\lambda 4}$ family rearrangement in the second round. And the like. LPHD, lymphocyte predominant Hodgkin's disease; MCHD, mixed cellularity Hodgkin's disease; NSHD, nodular sclerosis-type Hodgkin's disease. phocytes, monocytes, and even as dendritic cells. The major difficulty in determining the origin of these malignant cells lies in the disturbance caused by background cells. However, the "molecular histology" technique proposed by Küppers et al enables one to pick out individual H/R-S cells with typical morphology and surface markers in a histological section of tissue affected by Hodgkin's disease and determine whether the monoclonal or polyclonal rearrangements are derived from $\mathrm{H} / \mathrm{R}-\mathrm{S}$ cells or from other background cells in the specimen. Using this approach, ourselves and other workers have shown that Ig gene rearrangements occur in single H/R-S cells, so that it has gradually become clear that $\mathrm{B}$ cell malignant transformation occurs in these cells. ${ }^{514}$

Lymphocyte predominant Hodgkin's disease is a distinctive and rare form of the disease that is clinically indolent and has an excellent prognosis. The presence of H/R-S cells among a background of small lymphocytes and histiocytes has recently been classified as a special entity, distinct from classic Hodgkin's disease. ${ }^{15}$ H/R-S cells of lymphocyte predominant Hodgkin's disease have special immunophenotypic and genotypic characteristics, different from those of other subtypes of Hodgkin's disease. Expression of CD19, CD20, and CD45RB, but not of CD15 and CD30 is common. ${ }^{1}$ The detection of restricted Ig light chain mRNA supports the theory that lymphocyte predominant Hodgkin's disease is a monoclonal proliferation of $\mathrm{B}$ cells. $^{7-9}$ In many cases of lymphocyte predominant Hodgkin's disease, $\mathrm{H} / \mathrm{R}-\mathrm{S}$ cells with the molecular features of a monoclonal population of B cells were found, which were negative for Epstein-Barr virus (EBV), except in a few cases. ${ }^{16}{ }^{17}$ However, some investigators have reported evidence of the $B$ cell origin of H/R-S cells and the polyclonal nature of the disease. ${ }^{18}$ Our experiments corroborate the view that H/R-S cells of lymphocyte predominant Hodgkin's disease originate from B lymphocytes because of the $\mathrm{IgH}$ and $\kappa$ light chain gene rearrangements revealed in individual $\mathrm{H} / \mathrm{R}-\mathrm{S}$ cells of this type of Hodgkin's disease. These cells might represent a separate B cell clone, indicating a polyclonal population.

During B cell development, an $\operatorname{IgH}$ gene undergoes recombination through a rejoining of the $\mathrm{V}, \mathrm{D}$, and $\mathrm{J}$ regions, giving rise to a three part $\mathrm{V}_{\mathrm{H}} \mathrm{D}_{\mathrm{H}} \mathrm{J}_{\mathrm{H}}$ unit, which is called the complementary determining region III, and is a clonal signature of an individual $\mathrm{B}$ cell. If PCR is applied across this region, the lengths of the reaction products of different clonal B cells tend to differ. If single H/R-S cells from different areas of a specimen from a patient with Hodgkin's disease have the same size PCR products, we can assume that these H/R-S cells are derived from the same $\mathrm{B}$ cell clone.

With this method, the origin of $\mathrm{H} / \mathrm{R}-\mathrm{S}$ cells in mixed cellularity and nodular sclerosis types of Hodgkin's disease have been determined convincingly by ourselves and other workers. ${ }^{514}$ However, the clonality of $\mathrm{H} / \mathrm{R}-\mathrm{S}$ cells is discordant. Hansmann's group studied 14 cases of Hodgkin's disease, mainly of the two subtypes in 
which more H/R-S cells are present. In 13 of these cases, all the H/R-S cells from a given biospy specimen had the same, or very similar Ig gene rearrangements. These cells, therefore, were B cells derived from a single clone. The related and unrelated pattern of $\operatorname{IgH}$ gene rearrangements in 12 patients were observed by Hummel et al. They gave rise to a possibility of monoclonal and polyclonal H/R-S cells in the tumour tissues, although cellular contamination might account for these results. On the other hand, classic Hodgkin's disease with cells coexpressing CD20 and CD30 accounts for only $5-30 \%$ of all cases of Hodgkin's disease and the results of Hummel et al are therefore not relevant to most cases of Hodgkin's disease. ${ }^{120}$ In our series, patients $1,4,6$, and 7 had many cells expressing the same size of IgH rearrangement (80 bp). In addition to IgH, $\kappa$ and $\lambda$ light chain gene rearrangements were detected in all patients except patient 8 . The same light chain gene rearrangements were present simultaneously in two individual H/R-S cells from the same specimen $\left(\mathrm{V}_{k 4}\right.$ in patients 3 and $5 ; \mathrm{V}_{13}$ in patient 7). This result was confirmed by identifying identical rearrangements in cells from different sections. However, the family of different light chain gene rearrangements was also detected in cells from the same specimen (patients 2, 4, 5, and 7). Thus, it is likely that these cells in our series represented a different clonal B cell population at various stages of development. These H/R-S cells in a given biopsy specimen might be descendants of a single $\mathrm{B}$ cell and therefore constitute a monoclonal population, or each $\mathrm{H} / \mathrm{R}-\mathrm{S}$ cell might be from a separate B cell clone.

Why does light chain restriction almost always involves the $\kappa$ but not the $\lambda$ light chain? During $B$ cell development, functional heavy chain gene rearrangement is followed by $\kappa$ gene rearrangement. If $\kappa$ gene rearrangement on both chromosomes fails, the cell may proceed with $\lambda$ gene rearrangement to yield a functional $\lambda$ light chain gene. ${ }^{21}$ In humans, $\sim 40 \%$ of $\mathrm{B}$ cells express the $\lambda$ light chain. For this reason, at least some $\mathrm{H} / \mathrm{R}-\mathrm{S}$ cells should have rearranged $\lambda$ light chain genes. Our study showed this to be true: in addition to $\mathrm{V}_{\lambda_{3}}$ (patients 2 and 5 ) and $\mathrm{V}_{\lambda 4}$ family rearrangement, $\mathrm{V}_{\lambda 2,4}$, two different family rearrangements, which might be on just two chromosomes or on more than two chromosomes in hyperploid H/R-S cells, were detected.

There are still many questions to be answered about Hodgkin's disease, including: why H/R-S cells do not behave like EBV transformed B cells or the cells in any common B cell non-Hodgkin's lymphoma; how H/R-S cells stay alive; and the clonality of H/R-S cells. It is hoped that more carefully planned studies in the future will provide new insights that will clarify this enigmatic disease.

Our study was supported by the National Nature Science Foundation (39470291).

1 Drexler HG. Recent result on the biology of Hodgkin and Reed-Sternberg cells. I. Biopsy material. Leuk Lymphoma 1992;8:283-313.

2 Mimose H, Chen Y-Y, Ben-Ezra J, et al. Nodular lymphocyte predominant Hodgkin's disease: study of lymphocyte predominant Hodgkin's disease: study of
immunoglobulin light chain protein and mRNA expresimmunoglobulin light chain protein
sion. Hum Pathol 1992;23:1115-19.

3 Ruprai AK, Pringle JH, Angel CA, et al. Localization of immunoglobulin light chain mRNA expression in Hodgkin's disease by in situ hybridization. F Pathol 1991;164:37-40

4 Stoler MH, Nichols GE, Symbula M, et al. Lymphocyte predominance Hodgkin's disease. Evidence of a $\kappa$ light chain-restricted monotypic B-cell neoplasm. Am f Pathol 1995;146:812-18.

5 Küppers R, Rajewsky K, Zhao M, et al. Hodgkin's disease: Hodgkin and Reed-Sternberg cells picked from histological sections show clonal immunoglobulin gene rearrangements and appear to be derived from B cells at various stages of development. Proc Natl Acad Sci USA 1994;91:10962-6.

6 Küppers R, Zhao M, Hansmann ML, et al. Tracing B cell development in human germinal centers by molecular analysis of single cells picked from histological sections.

7MBO $1993,12.4955-67$.

Deane M, Norton JD. Immunoglobulin heavy chain variable region family usage is independent of tumor cell phenotype in human B lineage leukemia. Eur f Immunol 1990;20: 2209-12.

8 Griesser $\mathrm{H}$. Applied molecular genetics in the diagnosis of malignant non-Hodgkin's lymphoma. Diagn Mol Pathol 1993;2:177-80.

9 Inghirami G, Szabolcs MJ, Yee HT, et al. Detection of immunoglobulin gene rearrangement of B cell nonHodgkin's lymphoma and leukemia in fresh, unfixed and formalin-fixed, paraffin-embedded tissue by polymerase chain reaction. Lab Invest 1993;68:746-57.

10 Küppers R, Willenbrock K, Rajewsky K, et al. Detection of clonal $\lambda$ light chain gene rearrangements in frozen and paraffin-embedded tissues by polymerase chain reaction. Am f Pathol 1995;147:806-14.

11 Küppers R, Zhao M, Rajewsky K, et al. Detection of clonal $\mathrm{B}$ cell populations in paraffin-embedded tissues by polymerase chain reaction. Am f Pathol 1993;143:230-9.

12 Treamoto R, Akasgi T, Yoshino T, et al. Direct detection of Epstein-Barr virus DNA from a single Reed-Sternberg cell of Hodgkin's disease by polymerase chain reaction. $\mathscr{f} p n \mathcal{F}$ Cancer Res 1992;83:329-33.

13 Lorenzen J, Wintzer C, Zhao-Hohn M, et al. Single-cell analysis of $T$ cell receptor- $\gamma$ rearrangements in large cell anaplastic lymphoma. Diagn Mol Pathol 1996;5:10-19.

14 Hummel M, Ziemann K, Lammert H, et al. Hodgkin's disease with monoclonal and polyclonal populations of ReedSternberg cells. N Engl F Med 1995;333:901-6.

15 Chan JKC, Banks PM, Cleary ML, et al. A revised European-American classification of lymphoid neoplasms proposed by the international lymphoma study group. A proposed by the international lymphoma study group. A
summary version. Am $\mathcal{F}$ Clin Pathol 1995; 103:543-60.

16 Marafioti T, Hummel M, Anagnostopoulos I, et al. Origin of nodular lymphocyte-predominant Hodgkin's disease from a clonal expansion of highly mutated germinal-center B cells. N Engl F Med 1997;337:453-8.

17 Ohno T, Stribley JA, Wu G, et al. Clonality in nodular ymphocyte-predominant Hodgkin's disease. $N$ Engl f Med 1997;337:459-65.

18 Delabie J, Tierens A, Wu G, et al. Lymphocyte predominance Hodgkin's disease: lineage and clonality determination using a single-cell assay. Blood 1994;84:3291-8.

19 Zukerberg LR, Collins AB, Ferry JA, et al. Coexpression of CD15 and CD20 by Reed-Sternberg cells in Hodgkin's disease. Am f Pathol 1991;139:475-83.

20 Agnarsson BA, Kadin ME. The immunophenotype of Agnarsson BA, Kadin ME. The immunophenotype of
Reed-Sternberg cells: a study of 50 cases of Hodgkin's disReed-Sternberg cells: a study of 50 cases of Hodgkin's dis-
ease using fixed frozen tissues. Cancer 1989:63:2083-7.

21 Graninger WB, Goldman PL, Morton CC, et al. The $\kappa$ deleting element. $\mathcal{F}$ Exp Med 1988;167:488-501. 